IP Periodica Polytechnica Civil Engineering

\author{
60(4), pp. 611 617 2016 \\ DOI: $10.3311 /$ PPci.8727 \\ Creative Commons Attribution (1) \\ RESEARCH ARTICLE
}

\section{Fresh State Properties of Concrete Incorporating Scrap Tire Rubber}

\author{
Malika Medine, Habib Trouzine, José Barroso De Aguiar
}

Received 31-10-2015, revised 15-01-2016, accepted 23-02-2016

\begin{abstract}
The purpose of this work is to study fresh lightweight concrete containing recycled tire rubber aggregates. An experiment on concrete obtained by incorporating rubber aggregate with a ratio replacement of 5, 7.5 and $10 \%$ is done to evaluate the effect of these aggregates on the workability of two sets of concrete specimens. In the first set, coarse aggregates were replaced by different percentages by weight of granulate rubber and in the second set both coarse aggregates and sand were replaced rubber granulate and crumb rubber. Density, air content, compaction and slump tests are performed on the seven mixtures. Taking into account the density and water absorption differences between the natural aggregates and the rubber aggregates, the validity of the tests results are discussed. The results show that incorporating these rubber aggregates affects most rheological properties of lightweight concrete, for some application of concrete incorporating waste tire, rubber particles should be treated.
\end{abstract}

\section{Keywords}

Concrete $\cdot$ Fresh state $\cdot$ Rheological properties $\cdot$ Workability . Rubber

\section{Malika Medine}

Civil Engineering Department, Faculty of Technology, Sidi Bel Abbes University, Sidi Bel Abbes, Algeria

\section{Habib Trouzine}

Civil Engineering Department, Faculty of Technology, Sidi Bel Abbes University, Sidi Bel Abbes, Algeria

e-mail: h_trouzine@yahoo.fr

\section{José Barroso De Aguiar}

Civil Engineering Department, School of Engineering, University of Minho, Guimaraes, Portugal

\section{Introduction}

Consequence of the rapid growth of consumer products such as tires has greatly induced environmental problems. Algeria alone generates approximately 25918.50 tons/year of used tires [1]. Numerous technical solutions and integrated management system related to end of life tyres are proposed [2, 6].

The growing interest in utilizing waste material in civil engineering applications has opened the possibility of constructing with unconventional materials. Cement-based materials are characterized by their poor ductility and are sensitive to cracking, particularly to shrinkage cracking, due to the rigidity. The concrete incorporating tire rubber waste is expected to have higher fracture and cracking resistance. Siddique and Naik [7], Khaloo et al. [8] showed in an experimental investigation that the addition of rubber decreases the material unit weight. For structural applications of lightweight concrete, strength decreased and reduces the dead load, foundation size and construction coasts.

Many researchers are interested in the study of the properties at hardened state of concrete containing tire waste tire but very few of them have thought about the properties at fresh state of this type of concrete. Slump tests were performed on rubberized concrete by Raghvan et al. [9], Khatib and Bayomy [10], Aiello and Leuzzi [2]. Air content tests were performed by Fedroff et al. [11] et Khatib and Bayomy [10].

The behavior of fresh concrete from mixing up to compaction depends mainly on the property called "workability of concrete". In general terms, workability represents the amount of work which is to be done to compact the concrete in a given mould. ASTM C 125 - 03 [12] describes workability of concrete as "that property determining the effort required to manipulate a freshly mixed quantity of concrete with minimum loss of homogeneity." Workability can be affected by: specific surface area of the cement, water content, surface texture of aggregate, use of admixtures, mix proportions, shape and grading of aggregates. Workability depends not only on the properties of the concrete, but also on the nature of the application.

More than 60 test methods for measuring concrete workabil- 
ity have been developed for a single project or for a specific application and have been sparsely reported in the literature [13].

Several researchers have studied the workability of rubberized concrete but without considering the lightness of rubber aggregate and their lower water absorption, for this an experimental program was undertaken. Its aims to investigate properties of fresh scrap tire reinforced concrete.

This work aimed to examine workability of six mixtures of lightweight concrete incorporating scrap tire aggregates which are compared with referential plain concrete. Slump, air content, density and compaction tests were performed on the seven fresh concrete mixtures but also the bleeding speed, segregation degree and gravel and rubber forces undergoing are examined

\section{Materials}

\subsection{Scrap tire rubber}

Tire rubber particles consist of a complex mixture of elastomers, polyisoprene, polybutadiene and styrene-butadiene. Stearic acid (1.2\%), zinc oxide (1.9\%), extender oil (1.9\%) and carbon black $(31.0 \%)$ are also important components of tires [14, 15]. The rubber particles Fig. (1) were obtained by manual shredding at ambient temperature $\left(20^{\circ} \mathrm{C}\right)$. They are characterized by different size and shape. These aggregates have rough and flat surfaces, containing textile fibers. A 24 hours water absorption, in normal conditions of temperature and pressure, of the rubber particles is about $0.1 \%$

\subsection{Aggregates}

Figure 2 shows the grading curves of used sand, gravel, granule rubber and crumb rubber. It should be noted that there is a slight difference between the grading of the natural aggregates and rubber aggregates since the latter has been shredded manually.

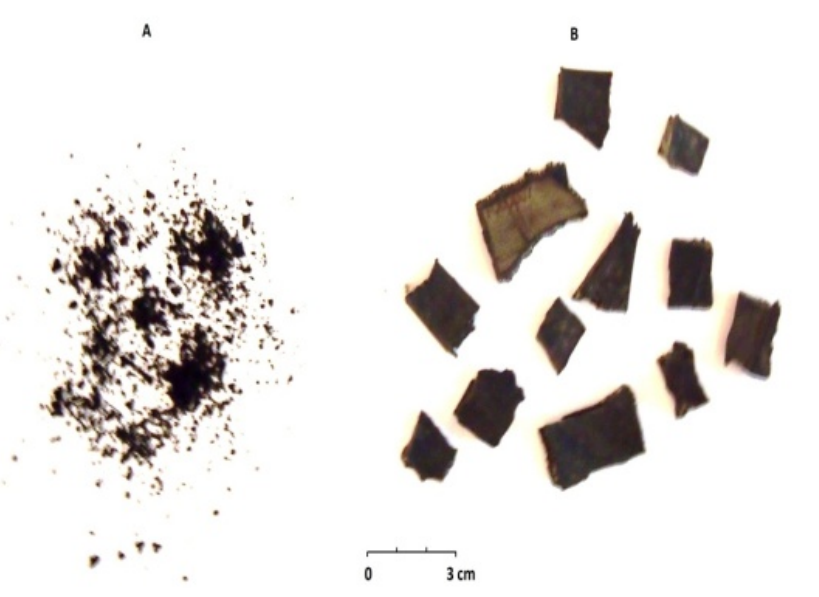

Fig. 1. (A) Crumb rubber (B) Granules rubber

\subsection{Mixtures design}

Preparation and mixing of concrete specimens were done at room temperature. For all mixtures the cement content was

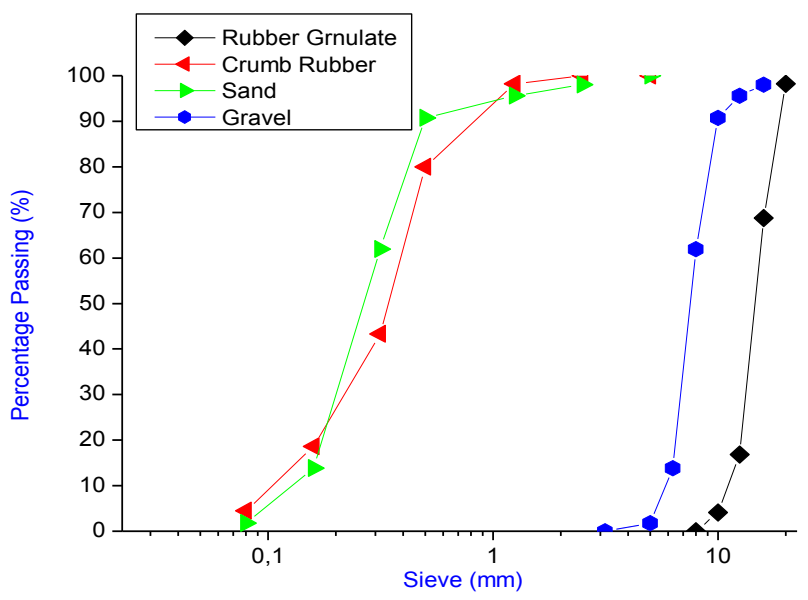

Fig. 2. Granding curves

$380 \mathrm{~kg} / \mathrm{m}^{3}$, the water-cement ratio was 0.5 . For the lightweight mixtures, first, the gravel fraction of aggregate grading was substituted by granules rubber in different weight ratios, then gravel and sand were substituted with granule rubber and crumb rubber in the same weight ratios. Table 1 displays the concrete compositions where each mixtures is coded using the format $C X x n$.

The letter $\mathrm{C}$ indicates concrete $C r e f$ indicates referential concrete (no substitutions). $R$ indicates granules rubber replacing a gravel fraction of aggregate. $R m$ indicates granules rubber and crumb rubber replacing a gravel and sand fraction of aggregate and $n$ indicates ratio of substitution.

The ratios of substitution were ; 7.5 and $10 \%$ by weight. For example $C R m 7.5$ is lightweight concrete incorporating $7.5 \%$ of granules rubber and crumb rubber in mixed replacement by weight of gravel and sand.

Tab. 1. Mixtures composition

\begin{tabular}{lccccc}
\hline \multirow{2}{*}{ Concrete } & \multicolumn{5}{c}{ Materials $\left(\mathrm{kg} / \mathrm{m}^{3}\right)$} \\
\cline { 2 - 6 } & Cement & $\begin{array}{c}\text { Granule } \\
\text { rubber }\end{array}$ & $\begin{array}{c}\text { Crumb } \\
\text { rubber }\end{array}$ & Sand & Gravel \\
\hline Cref & 380 & 0 & 0 & 858 & 927 \\
\hline$C R g 5$ & 380 & 46.4 & 0 & 858 & 884 \\
\hline$C R g 7.5$ & 380 & 69.5 & 0 & 858 & 851 \\
\hline$C R g 10$ & 380 & 93 & 0 & 858 & 839 \\
\hline$C R m 5$ & 380 & 46.4 & 42.9 & 815 & 884 \\
\hline$C R m 7.5$ & 380 & 69.5 & 64.35 & 793.65 & 851 \\
\hline$C R m 10$ & 380 & 93 & 85.8 & 772.2 & 839 \\
\hline
\end{tabular}

\section{Fresh state methods}

\subsection{Slump test}

The slump test was developed in the early 20th century; concrete researchers were just beginning to recognize the importance of water content in predicting concrete strength [16].

The slump test gives an indication of the water content, thus the hardened strength of concrete. The ability to improve strength by controlling concrete consistency represented a new 
advance for the concrete industry. The slump test was quickly adopted because of its simplicity [13,17].

Raghvan et al. [9] have reported that mortars incorporating rubber shreds achieved workability (defined as the ease with which mortar/concrete can be mixed, transported and placed) comparable to or better than a control mortar without rubber particles.

Khatib and Bayomy [10] investigated the workability of rubberized concrete and reported that there is a decrease in slump with increase in rubber content as a percentage of total aggregate volume. They further noted that at rubber contents of $40 \%$, slump was almost zero and concrete was not workable manually. It was also observed that mixtures made with fine crumb rubber were more workable than those with coarse tire chips or combination of tire chips and crumb rubber.

Aiello and Leuzzi [2] noted that workability of fresh concrete is slightly improved by the partial substitution of coarse or fine aggregate with rubber shreds. This means that rubberized concrete can be mixed, cast and vibrated using equipment and procedures adopted for conventional concrete.

For this study, slump tests were performed according to the standard NF P 18-437 [18].

\subsection{Bleeding and Segregation Measurement}

The bleeding speed and segregation degree were quantified and their method is described in [19]. A sample of concrete of $3000 \mathrm{ml}$ was put into a container with $15 \mathrm{~cm}$ diameter and $30 \mathrm{~cm}$ height. The concrete was equally tamped for 10 times by a tamper and the surface was flattered. The container was putted on ground and stayed immobile for $30 \mathrm{~min}$, then a burette was used to assimilate the water bleeding on the surface of the concrete, and the volume of bleeding water was measured with a $5 \mathrm{ml}$ graduate. As shown in Fig. 3 the $1000 \mathrm{ml}$ concrete top level and $1000 \mathrm{ml}$ concrete down level were taken, the mortar and sand were washed, and the gravel's weight were measured. The bleeding parameter $B$ is defined as shown in the following equation,

$$
B=\frac{V_{b}}{V_{w}} 100
$$

Where $V_{b}$ is the volume of surface bleeding and $V_{w}$ is the volume of water in the sample.

The segregation parameter $V$ is defined as shown in the following equation,

$$
V=\frac{m_{2}}{m_{1}}
$$

Where $m_{2}$ the gravel's weight of the down level and $m_{1}$ is the gravel's weight of the up level.

In practical working situations, $B$ less than 1 means good bleeding resistance, and $V$ less than 1.1 means good segregation resistance.

Because rubber density is about 0.92 (lower than 1), granule rubber and crumb rubber are concentrated in the up level
(Fig. 3). For this, for concrete incorporating rubber, Eq. (2) is altered as shown in Eq. (3). The segregation parameter is calculated as the sum of segregation parameters of gravel's and rubber's aggregates.

$$
V^{\prime}=\frac{m_{2} \cdot m_{1}^{\prime}+m_{1} \cdot m_{2}^{\prime}}{m_{1} \cdot m_{1}^{\prime}}
$$

Where $m_{2}$ and $m_{2}^{\prime}$ are gravel's and rubber's weights of the down level and $m_{1}$ and $m_{1}^{\prime}$ are gravel's and rubber's weights of the up level.

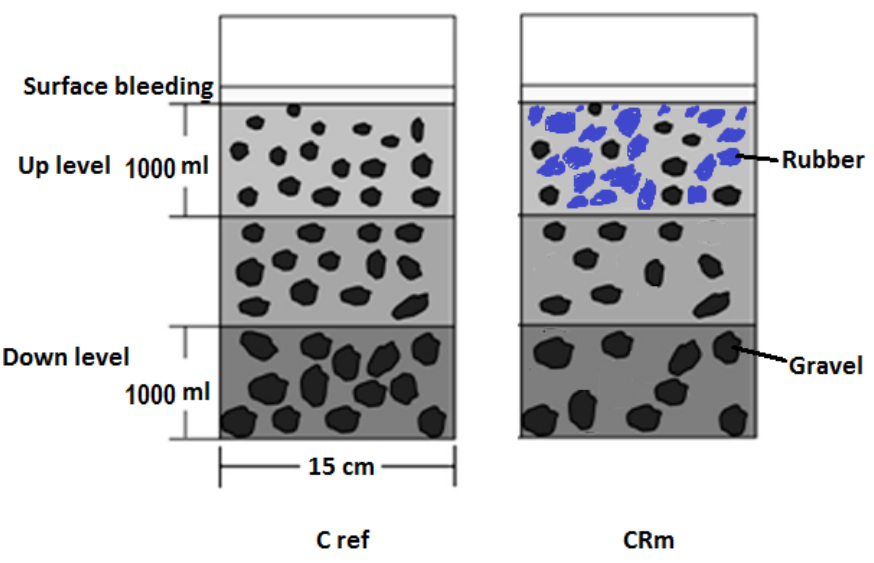

Fig. 3. $3000 \mathrm{ml}$ sample sketch map for referential and lightweight concretes

Models for estimating the yield stress are numerous. However, these models are mainly applicable to powder suspensions, and according to Touto and Roussel [20], they cannot be applied to fresh concrete.

Hu et al. [21] developed an expression for yield stress in terms of slump and density, as shown in Eq. (4). Ferraris and De Larrard [22] altered equation [4] as shown in Eq. (5). Murata and Kikukawa [23] developed an empirical equation for yield stress in terms of slump for concretes, as shown in Eq. (6). Table 2 summarize yield stress expressions.

Figure 4 shows the forces exerting on rubber and gravels in concrete, $G_{1} / G_{2}$ ratio is greater than 2 , so the gravity pulls the gravels down, which is resisted by mortar, finally equilibrium is reached to form the aggregates distribution, this is the process of segregation. Recently Spangenberg et al. [24] studied the aggregate migration patterns during fluid concrete castings and the aggregates' distribution relating to the rheology parameters. The speed of gravel's going down is very slow so the viscosity's impact on the segregation is not obvious. On the other hand, as segregation is the result of stone's gravity overcomes the shearing stress of the mortar at very slow velocity, the segregation is dominated by the yield stress.

\subsection{Density}

Even if any concrete contains sufficient water to fill the voids of the solid skeleton, there is always a certain volume of air. The quantitative evaluation of the air entrapped predicts the mechanical properties of the hardened concrete. There are three 
Tab. 2. Yield stress expressions

\begin{tabular}{|c|c|c|c|}
\hline Authors & Equations & & Conditions \\
\hline \multirow{2}{*}{ Hu et al. (1996) } & $\tau_{0}=\frac{\rho}{270}(300-s)$ & (4) & slumps greater than approximately \\
\hline & $\begin{array}{c}\tau: \text { yield stress in } \mathrm{Pa}, \\
s: \text { slump in } \mathrm{mm} \\
\rho: \text { density in } \mathrm{kg} / \mathrm{m}^{3}\end{array}$ & & $10 \mathrm{~cm}$ \\
\hline
\end{tabular}

\begin{tabular}{|c|c|c|c|}
\hline Ferraris and De Larrard (1998) & $\begin{array}{c}\tau_{0}=\frac{\rho}{347}(300-s)+212 \\
\tau: \text { yield stress in } \mathrm{Pa} \\
s: \text { slump in } \mathrm{mm} \\
\rho: \text { density in } \mathrm{kg} / \mathrm{m}^{3}\end{array}$ & (5) & slump higher than $100 \mathrm{~mm}$ \\
\hline Murata and Kikukawa (1992) & $\begin{array}{c}\tau_{0}=714-473 \log (s) \\
\tau: \text { yield stress in } \mathrm{Pa} \\
s: \text { slump in } \mathrm{cm}\end{array}$ & (6) & $\begin{array}{l}\text { slumps ranging from } 12.5 \mathrm{~cm} \text { to } 26 \\
\mathrm{~cm}\end{array}$ \\
\hline
\end{tabular}

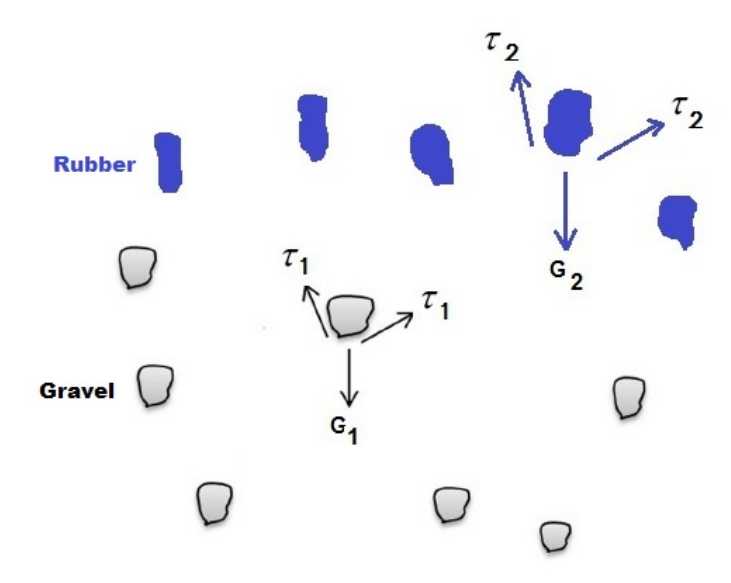

Fig. 4. Gravel and rubber forces undergoing

methods to measure this parameter: gravimetric, volumetric and pressure meter method. The pressure meter method [25] is used in our test because it is considered as most reliable and accurate method.

\subsection{Air content}

Air content concrete is typically specified in areas of the country where frost-related damage can occur. The measurement of air content in fresh concrete of normal density is typically performed using the pressure method [26].

Fedroff et al. [11] have reported higher air content in rubberized concrete mixtures than control mixtures even without the use of air-entraining admixture (AEA). Similar observations were also made by Khatib and Bayomy [10]. This may be due to the non-polar nature of rubber particles and their tendency to entrap air in their rough surfaces.

Also when rubber is added to a concrete mixture, it may at- tract air as it has the tendency to repel water, and then air may adhere to the rubber particles. Therefore, increasing the rubber content results in higher air contents in rubberized concrete mixtures, thereby decreasing the unit weight of the mixtures [7].

Low density seems to be one of the major characteristics of lightweight concretes, its determination is therefore essential. The measurements are carried out according to NF P18-440 standard [27].

\subsection{Compaction Test}

Like the compaction factor test, the compaction test [28,29] expresses workability in terms of compactability of a concrete sample. The test was developed during the 1960s in Germany and is standardized in Europe as EN 12350-4 [30]. The test apparatus, is extremely simple. It consists merely of a tall, rigid metal container with side dimensions of $200 \mathrm{~mm}$ and a height of $400 \mathrm{~mm}$. The top of the container is open. This latter is filled with fresh concrete without compaction. After the top of the filled container has been strucked, the concrete is compacted with a tamping rod or, more commonly, with vibration until the concrete ceases to subside in the box. According to the European standard, EN12350-4 [30], the concrete must be compacted using an internal or external vibrator operating at a specified frequency. The distance from the top of the concrete to the top of the container is measured at the four corners of the container. The degree of compaction is calculated as the height of the container divided by the average height of the compacted concrete.

Typical test results range from 1.02 to 1.50 . Unlike the compaction factor test, a standard amount of energy is not imparted into the system. 


\section{Results and discussions}

\subsection{Measurement of Slump (Abrams Cone)}

The consistencies was measured with slump test are of the order of $5 \mathrm{~cm}$ (Fig. 5), which corresponds to lightweight concretes farms requiring energy in its installation. It is noted that the addition of rubber granulates has decreased workability of the mixtures studied. Several researchers have shown that the shape and texture of rubber aggregates significantly affects the workability of concretes [13, 31, 32]. Thus, the deviation of the spherical shape leads to increase viscosity. This necessitates a higher volume of paste to be able to rotate freely and avoid interaggregate friction.

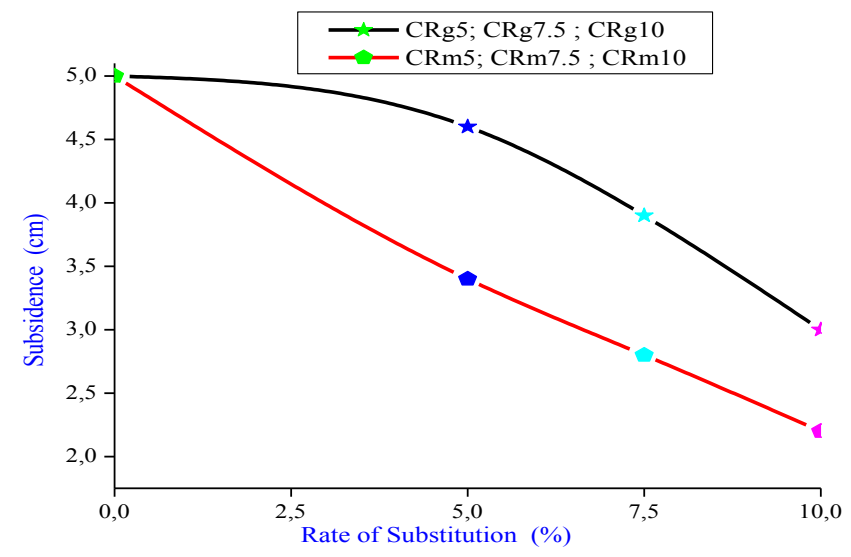

Fig. 5. Slump of lightweight concretes in function of rate of substitution

\subsection{Bleeding and segregation resistance}

Bleeding parameter $B$ for referential concrete was less than 1 which means good bleeding resistance, but for concrete incorporation scrap tire rubber $B$ was equal or more than 1 (Fig. 6). The biggest value was observed for $C R m 7.5$ and $C R m 10$, this can be due to the rubber granule content and the lowest water absorption of rubber. Ab-Malek and Stevenson [33] studied the effect of 42-year immersion in seawater on natural rubber; they concluded that the water absorbed by the rubber was less than $5 \%$ of its dry mass.

The segregation parameter $V$ is used to evaluate the degree of segregation, a larger $V$ indicates more segregation of the aggregates. When $V$ is lower than 1.1, the concrete would not see apparently segregation, this can be considered as negligible and the concrete has good segregation resistance [19].

Values of segregation parameters were computed using Eqs. (2) and (3), it is necessary to specify than for concrete incorporating scrap tire rubber $m_{2}^{\prime}$ tends to zero for $21 / 35$ cases. Rubber aggregate are concentrated in the up level. For referential concrete the segregation parameter is less than 1.1 which means good segregation resistance. For concrete incorporation scrap tire rubber $V$ ranges from 1.1 to 1.5 when $V^{\prime}$ ranges from 1.15 to 1.3 (Fig. 6).

Figure 6 show values of bleeding and segregation parameters for studied mixtures.

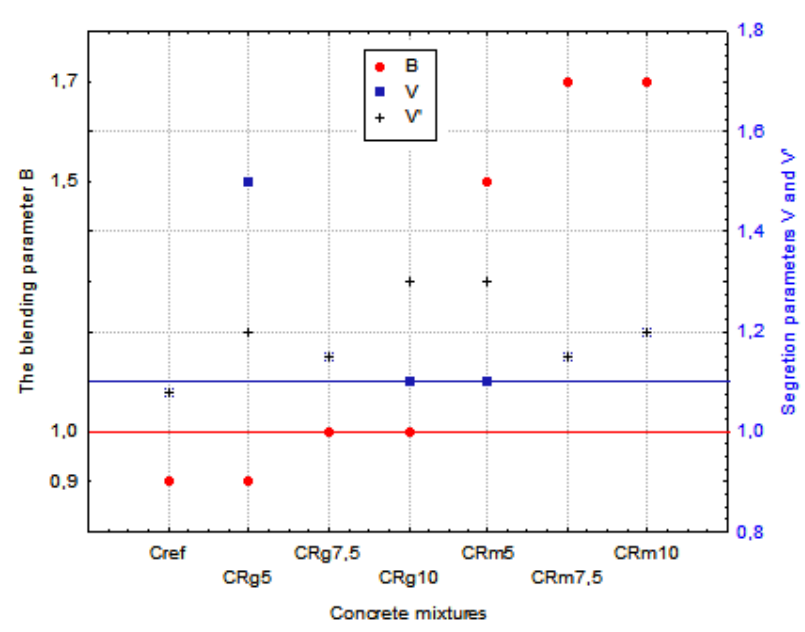

Fig. 6. Bleeding and segregation parameters for concrete mixtures

The concrete with good segregation resistance have the yield stress ranging from $300 \mathrm{~Pa}$ to $2000 \mathrm{~Pa}$, and the viscosity ranging from $3 \mathrm{~Pa} \cdot \mathrm{s}$ to $43 \mathrm{~Pa} \cdot \mathrm{s}$ [24]. For referential concrete the value of yield stress according to Eq. (4) is $2175 \mathrm{~Pa}$ when it's only about 1905 Pa using Eq. (5), it's not possible to use Eq. (6) since the condition on slumps values are not verified. Interestingly values of yield stress for concrete incorporating scrap tire range from 2182 to $2333 \mathrm{~Pa}$ using Eq.144 and 1910 to $2027 \mathrm{~Pa}$ using Eq. [5].

\subsection{Density}

The densities of lightweight concretes were measured immediately after mixing. The lowest value corresponds to $C R m 10$ (Fig. 77, which is logical given the amount and form of the rubber aggregates introduced into its composition. Overall the obtained results express a steady fall in the density in presence of these aggregates which was demonstrated in several research projects [34].

\subsection{Air Content}

This test is used to measure the total air content of fresh concrete and to test whether the concrete is fully compacted.

In this research it was found that the air content of the lightweight concretes tested was between 2.45 and $3.1 \%$, this parameter increases with the rate of substitution.

In particular, the air occluded measured for each of the six lightweight concretes is entirely acceptable. Also, its presence in concrete is inevitable (without air-entraining) after drying, and may reach 2 to 5\%. Fedroff et al. [11]; Naik and Siddique [34] have shown that during mixing the rubber aggregates have an ability to trap air in the surface roughness increasing significantly the volume of air in the concrete. So shape, size and quantity of the rubber aggregates used in lightweight concretes obtained (particularly in CR10) are responsible of the increasing of air content. Several hypotheses can be advanced as explanations i.e. it is impossible to judge the influence of $w / c$ ratio (0.5) 


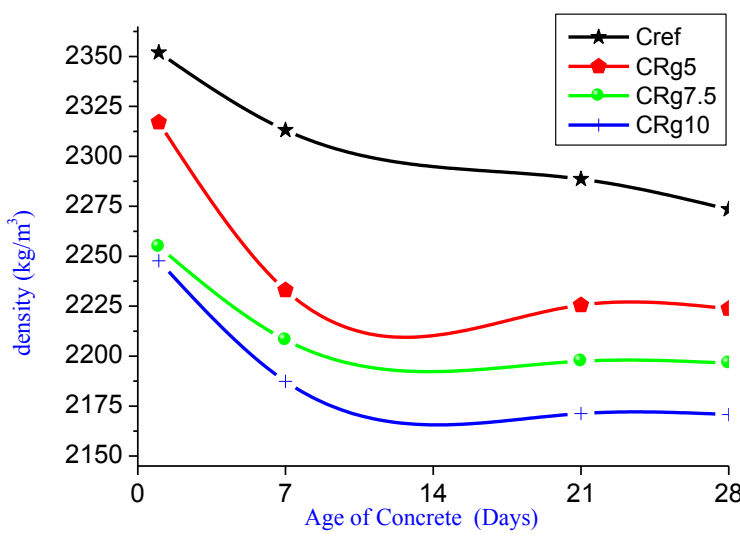

(a)

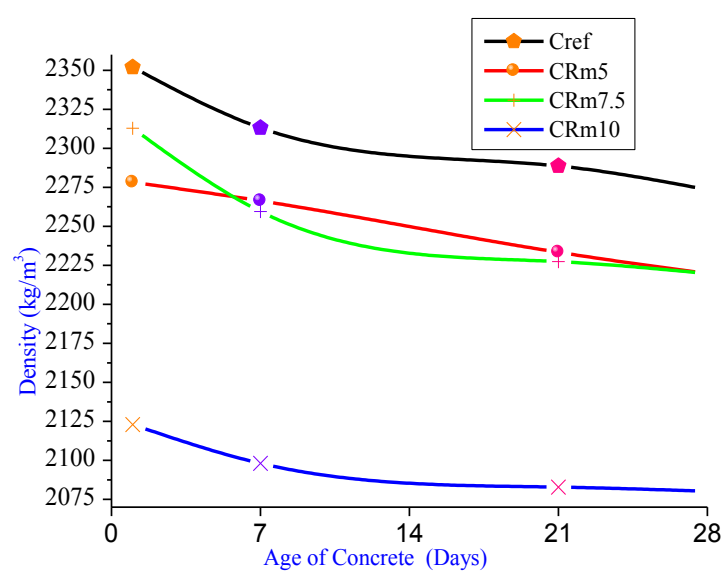

(b)

Fig. 7. (a) Values of fresh density in function of rate of substitution for set one; (b) Values of fresh density in function of rate of substitution for set two

on lightweight concretes studied, since this ratio was maintained constant.

\subsection{Compaction Test}

The compactness has been described to date as property affecting the quality of the finished product. It is difficult to give absolute values for this parameter, ensuring easy installation of fresh lightweight concrete [35].

However, it exists in the literature experimental research made on samples of concretes in situ but the lightweight concrete is not found [36]. As regards this research (Fig. 8) lightweight concretes obtained from both compositions are in the second class (Table 3 .

During the execution of this test, the rubber aggregates tend to concentrate on the surface of the sample (segregation phenomenon) and oddly all mixtures tested belong to the same compacting classes. This can be explained as the test is not suitable for this type of concrete.

\section{Conclusions}

The present work has investigated the effect of scrap tire rubber on the fresh state properties of concrete. Rubber aggregates
Tab. 3. Compacting classes in function of degree of compatibility

\begin{tabular}{|c|c|c|c|c|c|}
\hline $\begin{array}{l}\text { compacting } \\
\text { class }\end{array}$ & & $C 0$ & $C 1$ & $C 2$ & $C 3$ \\
\hline$h 1 /(h 1-S)$ & $\geq$ & 1,46 & 1.45 to 1.26 & 1.25 to 1.11 & 1.10 to 1.04 \\
\hline Cref & & - & - & 1.205 & - \\
\hline CRg5 & & - & - & 1.194 & - \\
\hline CRg7.5 & & - & - & 1.183 & - \\
\hline$C R g 10$ & & - & - & 1.176 & - \\
\hline$C R m 5$ & & - & - & 1.146 & - \\
\hline$C R m 7.5$ & & - & - & 1.169 & - \\
\hline$C R m 10$ & & - & - & 1.152 & - \\
\hline
\end{tabular}

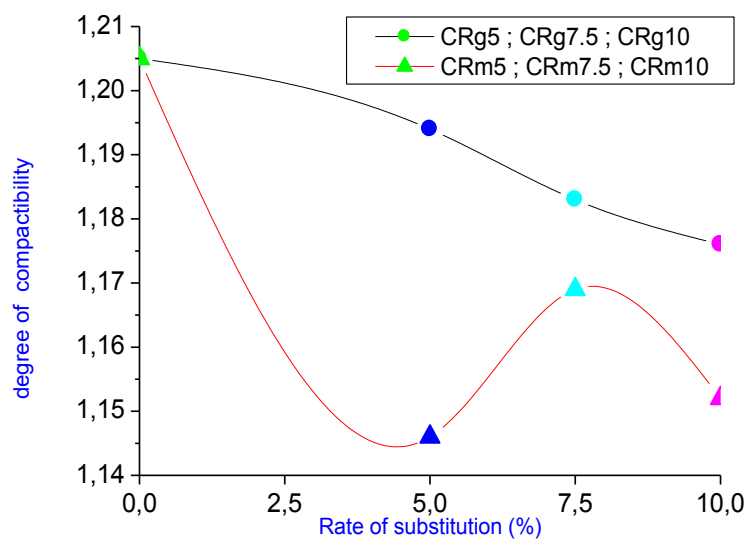

Fig. 8. Compactibility of lightweight concretes incorporating rubber

have rough and flat surfaces and are with lower density with very low water absorption compared to gravel, all this affect the fresh state properties of concrete incorporating scrap tire rubber. Fresh concrete density and subsidence decreased with increase in rubber content. The measured air occluded for concretes incorporating rubber aggregate is entirely acceptable. The bleeding parameter increases when scrap rubber content is important since rubber water absorption is low.

Although the segregation of rubber aggregate is visible, values of the segregation parameter $V$ shown acceptable segregation resistance, for this equation of $V$ may be altered as the sum of segregation parameters of gravel's and rubber's aggregates. As suspected values of yield stress are affected by the increase of rubber aggregate since the density of rubberized concrete decrease with the increase of rubber aggregate content. For some application of concrete incorporating waste tire, rubber particles should be treated.

\section{References}

1 Trouzine H, Asroun A, Asroun N, Belabdelouhab F, Long NT, Problématiques des pneus usés en Algérie (Problematic of waste tires in Algeria), Nature \& Technologie, 5, (2010), 28-35. in French.

2 Aiello MA, Leuzzi F, Waste tire rubberized concrete: Properties at fresh and hardened state, Waste Management, 30(8), (2010), 1696-1704, DOI 10.1016/j.wasman.2010.02.005

3 Aylón E, Fernández-Colino A, Murillo R, Navarro MV, García T, Mastral AM, Valorisation of waste tyre by pyrolysis in a moving bed reactor, Waste Management, 30(7), (2010), 1220-1224, DOI 10.1016/j.wasman.2009.10.001 
4 Bernardo M, Lapa N, Gonçalves M, Barbosa R, Mendes B, Pinto F, Gulyurtlu I, Toxicity of char residues produced in the co-pyrolysis of different wastes, Waste Management, 30(4), (2010), 628-635, DOI 10.1016/j.wasman.2009.10.015

5 Donatello S, Tyrer M, Cheeseman CR, EU landfill waste acceptance criteria and EU Hazardous Waste Directive compliance testing of incinerated sewage sludge ash, Waste Management, 30(1), (2010), 63-71, DOI 10.1016/j.wasman.2009.09.028

6 Uruburu A, Ponce-Cueto E, Cobo-Benita JR, Ordieres-Meré J, The new challenges of end-of-life tyres management systems : A Spanish case study, Waste Management, 33(3), (2013), 679-686, DOI 10.1016/j.wasman.2012.09.006

7 Siddique R, Naik TR, Properties of concrete containing scrap tire rubber" an overview, Waste Management, 24(6), (2004), 563-569, DOI 10.1016/j.wasman.2004.01.006

8 Khaloo RA, Dehestani M, Rahamatabadi P, Mechanical properties of concrete containing a high volume of tire-rubber particles, Waste Management, 28(12), (2008), 2472-2482, DOI 10.1016/j.wasman.2008.01.015

9 Raghavan D, Huynh H, Ferraris CF, Workability, mechanical properties and chemical stability of a recycled tire rubber-filled cementitious composite, Journal of Materials Science, 33(7), (1998), 1745-1752, DOI 10.1023/A:1004372414475

10 Khatib ZK, Bayomy FM, Rubberized portland cement concrete, Journal of Materials in Civil Engineering, 11(3), (1999), 206-213, DOI 10.1061/(ASCE)0899-1561(1999)11:3(206)

11 Fedroff D, Ahmad S, Savas BZ, Mechanical properties of concrete with ground waste tire rubber, Transportation Research Board, 1532, (1996), 6672, DOI 10.1016/j.wasman.2008.01.015

12 ASTM C 125-03: Standard Terminology Relating to concrete and concrete aggregates, ASTM International; West Conshohocken, USA, 2003.

13 Koehler EP, Fowler DW, Measuring the workability of high fines concrete, University of Texas; Austen, USA, 2003.

14 Themelis NJ, Wernick IK, Resource recovery from used rubber tires, Resources Policy, 25(3), (1999), 179-188, DOI 10.1016/S03014207(99)00025-2

15 Trouzine H, Bekhiti M, Asroun A, Effects of scrap tire rubber fibre on swelling behaviour of two clayey soils in Algeria, Geosynthetics International, 19(2), (2012), 124-132, DOI 10.1680/gein.2012.19.2.124

16 Wig RJ, Comparative tests of the strength of concrete in the laboratory and the field, In: Eighth Annual Convention, National Association of Cement Users, 8, 1912, pp. 552-552.

17 Abrams DA, Proportion Concrete Mixtures, 1922, pp. 174-181.

18 NF P 18-437 : Essai pour béton frais - Partie 1 : échantillonnage (Fresh concrete testing - Part 1: Sampling) in French, French Association of Normalization; France, 1999. in French.

19 Xie H, Liu F, Yang H, Chen J, Zhang J, Zuo C, Workability and proportion design of pumping concrete based on rheological parameters, Constructions and building Materials, 44, (2013), 267-275, DOI 10.1016/j.conbuildmat.2013.02.051

20 Toutou Z, Roussel N, Multi scale experimental study of concrete rheology: from water scale to gravel scale, Materials and Structures, 39(2), (2006), 189-199, DOI 10.1617/s11527-005-9047-y

21 Hu C, De Larrard F, Serdan T, Boulay C, Bosc F, Deflorenne F, Validation of BTRHEOM, the new rheometer for soft-to-fluid concrete, Materials and Structures, 29(10), (1996), 620-631.

22 Ferraris CF, De Larrard F, Modified Slump Test to Measure Rheological Parameters of Fresh Concrete, Cement, Concrete and Aggregates, 20, (1998), 241-247, DOI $10.1520 / C C A 10417$ J

23 Murata J, Kikukawa H, Viscosity equation for fresh concrete, ACI Materials Journal, 89(3), (1992), 230-237.

24 Spangerberg J, Roussel N, Hattel JH, Sarmiento EV, Zirgulis G,
Geiker MR, Patterns of gravity induced aggregate migration during casting of fluid concretes, Cement and Concrete Research, 42(12), (2012), 15711578, DOI 10.1016/j.cemconres.2012.08.007

25 NF P 18-443 : Essai pour béton frais - Partie 7: teneur en air-Méthode de la compressibilité (Testing fresh concrete - Part 7: Air-content, Method of compressibility), French Association of Normalization; France, 2001. in French.

26 ASTM C 231: Air Content of freshly mixed concrete by pressure method, ASTM International; Philadelphia, USA, 2002.

27 NF P 18-440: Essai pour béton frais - Partie 6 : masse volumique (Testing fresh concrete - Part 6: density), French Association of Normalization; France, 1999. in French.

28 Bartos PJM, Fresh concrete: Properties and tests, Developments in Civil Engineering, (1992), 53-185.

29 Bartos PJM, Sonebi M, Tamim AK, Workability and rheology of Fresh concrete: Compendium of tests, RILEM, 2002.

30 NF EN 12350-4: Essai pour béton frais Partie 4: Degré de compactabilité (Testing fresh concrete Part 4: Degree of compactability), French Association of Normalization; France, 2001. in French.

31 Garros M, Composites cimentaires incorporant des granulats caoutchouc Issus du broyage de pneus usagés: optimisation de la composition et caractérisation (Cementitious composites incorporating rubber aggregates Coming from grinding used tires: optimization of the composition and characterization), PhD thesis, INSA; Toulouse, France, 2007. in French.

32 Güneyisi E, Gesoğlu M, Özturan T, Properties of rubberized concretes containing silica fume, Cement and concrete research, 34(12), (2004), 2309 2317, DOI 10.1016/j.cemconres.2004.04.005

33 Ab-Malek K, Stevenson A, The effect of 42 year immersion in sea-water on natural rubber, Journal of of materials science, 21(1), (1986), 147-154, DOI $10.1007 / \mathrm{BF} 01144713$

34 Naik TR, Siddique R, Properties of concrete containing scrap tire rubber : An overview, The University of Wisconsin - Milwaukee, 2002. Report $\mathrm{N}^{\circ}$. CBU-06.REP-459.

35 De Larrard F, Concrete Mixture-Proportioning: A Scientific Approach, Modem Concrete Technology Series; London, 1999.

36 Topçu IB, Avcular N, Analysis of rubberized concrete as a composite material, Cement and Concrete Research, 27(8), (1997), 1135-1139, DOI 10.1016/S0008-8846(97)00115-4 